\title{
BEL OTOMATIS VIRTUAL DUAL CHANNEL BERBASIS
} ANDROID

\author{
Moch Yasin ${ }^{1)}$, Maisyatus Su'adaa Irfana ${ }^{2)}$ \\ ${ }^{1)}$ Fakultas Sains dan Teknologi Universitas Islam Negeri Sunan Ampel \\ JL. A. Yani 117, Surabaya, Jawa Timur, 60237, Telp. 031-8410298 Fax. 031-8413300 \\ ${ }^{33}$ Fakultas Vokasi Universitas Airlangga \\ Jl. Srikana 65 Surabaya, Jawa Timur, 60286, Telpon : 031-5033869, 031-5053156; Faks : 031-5053156 \\ e-mail: my@uinsby.ac.id ${ }^{1)}$, fanamoet@gmail.com ${ }^{2)}$
}

\begin{abstract}
Abstrak
Di dunia pendidikan baik formal maupun informal seperti pesantren bel digunakan sebagai penanda dimulai dan diakhirinya proses belajar mengajar atau kegiatan kegiatan yg dilakukan bersama sama. Zaman dahulu, bell masih berupa kentongan dan lonceng tetapi seiring perkembangan ilmu pengetahuan banyak bermunculan bel bel otomatis. SDIT Firdaus adalah salah satu Sekolah Dasar Islam yang ada di Kota mojokerto dan menjadi tempat implementasi hasil penelitian ini. SDIT Firdaus terdiri dari 12 kelas dan hanya memiliki satu kantin dengan luas terbatas sehingga mengharuskan sekolah ini memisahkan waktu istirahat menjadi beberapa waktu agar pelayanan terhadap siswa bisa tetap optimal dan tidak berdesakan. Sekolah ini juga membutuhkan untuk penyuaraan ayat-ayat Al-Quran tertentu pada kelas yang sedang beristirahat dengan tujuan untuk mempercepat menghafal Al-Quran. Penanda waktu juga harus dapat diubah dengan mudah untuk menyesuaikan dengan kebutuhan mendatang. Pemberitahuan informasi waktu secara manual mempunyai tingkat keakuratan beragam dikarenakan kesalahan operator pemberi informasi tersebut. Dalam penelitian ini akan dibahas tentang rancang bangun Bel Otomatis Virtual Dual Channel berbasis Android untuk menjawab semua permaslahan di SDIT FIRDAUS diantaranya perbedaan istirahat, sholat bersama sampai pada pembagian penggunaan kantin agar pelayanan tetap optimal dan berbagai tujuan lainya.hasil uji coba menunjukkan bahwa aplikasi mampu berjalan sebagaimana mestinya.
\end{abstract}

Kata Kunci: Bel Otomatis, Dual Channel, Android.

Abstract

In education institution, both formal and informal like Pesantren, bell is used as alert of the starting and ending time of learning or studying, or activity that is done together. Long time ago, the alert used is only a simpe bell. As the development of science, there are many automated bell invented. SDIT Firdaus is one of Islamic Elementary School which is located in Mojokerto city and become the implementation site of this research result. The school has 12 classes and has only 1 canteen with limited capacity that make the school separate the break time into 2 shifts in order that the service of the student is optimal and the student is not too crowded. This school also needs to play some verses of Al-Quran in the class that is having break time to speed up memorizing Al-Quran. The time and sound management should be easy to be configured for future schedule change. The manual alert has various accuracy rate because of the manual process from the operator. In this research, the making of automatic dual channel school bell based on android phone is discussed to solve the problem of SDIT Firdaus, which are playing scheduled alert of 2 different break time, praying and the use of canteen to optimize the service and other aims.

Keywords: Automatic School Bell, Dual Channel, Android. 


\section{PENDAHULUAN}

Bell adalah sebuah alat penanda yang banyak digunakan oleh masyarakat baik pribadi maupun intitusi pendidikan, biasanya bell digunakan untuk penanda adanyaTamu sehingga Tuan rumah akan tahu jika didepan rumah ada seseorang yang mempunyai kepentingan, hal ini sangat membantu baik dipihak tamu maupun tuan rumah. Begitu juga di dalam intitudi pendidikan, tidak hanya pendidikan formal, pendidikan informalpun sangat membutuhkan adanya bel, didalam pendidikanformal bel digunakan untuk penanda mengawali atau mengakhiri suatu pembelajaran dan di dalam pendidikan informal seperti pondok pesantren, bel digunakan untuk penanda akan dimulainya ibadah bersama, atau kegiatankegiatan lain di dalam pesantren. Hal ini menjadikan keberadaan bell sangat penting. Seiring dengan perkembangan teknologi, bel manual sudah mulai banyak ditinggalkan dikarenakan sangat rendah tingkat keakuratan, kesalahan sering terjadi pada opertor bel itu sendiri atau permaslahan teknis lain, selain itu bel manual tidak menjawab permaslahan adanya perbedaan jadwal di suatu lembaga yang mempunyai banyak kelas dengan aturan-aturan yang berbeda. Perkembangan teknologi memunculkan berbagai bel otomatis salah satunya adalah bel listrik menggunakan PC, namun bel listrik menggunakan PC masih terdapat banyak kekurangan diantaranya dana yang tidak sedikit, kurang praktis, membutuhkan banyak daya, serta kurang durable karena seringnya terjadi mati listrik sehingga operator harus menyalakan ulang komputer. Penelitian lain yaitu menggunakan Rasberry Pi dapat menjadi alternatif solusi namun system ini belum mampu menangani perbedaan jam istirahat, tidak menggunakan MiniLCD touchscreen dan belum mempunyai box komponen sehingga masing kurang rapi. Oleh karena itu, didalam penelitian ini Telah dilakukan telaah mengenai sistem bel pelajaran yang sesuai dengan kebutuhan SDIT Firdaus, menggunakan MiniLCD touchscreen di Handphone Android dengan kapasitas simpan banyak dan interface yang userfriendly. Sistem ini juga hemat energi karena amplifier yang digunakan hanya menyala pada saat dibutuhkan.

A. Rumusan Masalah

1. Bagaimana mendesain Bel Otomatis Dual Channel berbasis Android dengan menggunakan 3 Timer

2. Bagaimana membuat dan mengimplementasi Bel Otomatis Dual Channel berbasis Android di SDIT Firdaus

B. Tujuan Masalah
1. Mendesain Bel Otomatis Dual Channel berbasis Android menggunakan 3 Timer yang sesuai dengan kebutuhan di SDIT FIRDAUS

2. Membuat dan mengimplementasikan Bel Otomatis Dual Channel berbasis Android menggunakan 3 Timer di SDIT FIRDAUS

C. Batasan Masalah

1. Dua Channel

2. Timer hanya bisa menangani 8 On dan 8 AND

3. Disesuaikan dengan kebutuhan SDIT Firdaus yang terdiri dari 12 kelas

\section{TINJAUAN PUSTAKA}

untuk penegasan; jangan menggunakan garis bawah.

Untuk memasukkan gambar di Word, letakkan.

\section{METODOLOGI}

Metode rancang bangun yang digunakan pada penelitian ini terdiri dari beberapa tahapan yaitu: (1) Analisis kebutuhan sistem, (2) Desain Sistem, (3) Disain tampilan alat, (4) Pembuatan alat (5) Pengujian Sistem.

A. Analisis Kebutuhan Sistem

Pada tahapan ini dilakukan analisa terhadap kebutuhan fungsional dan non fungsional.

Berikut adalah kebutuhan fungsional digambarkan ke dalam diagram use case sebagaimana ditunjukkan di gambar 1.

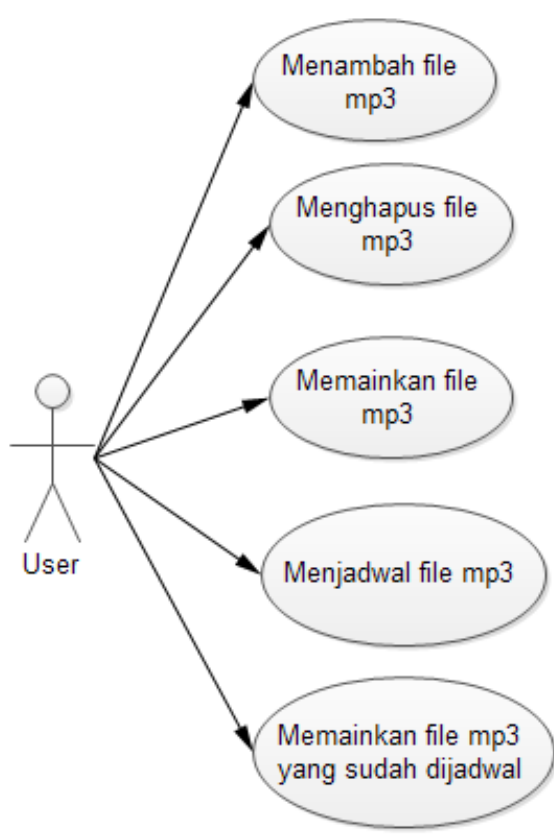

Gambar 1 Diagram Usecase

Kebutuhan non fungsional adalah sebagai berikut

1. Proses menambah file mp3 harus dapat dilakukan dengan menggunakan Bluetooth, komputer, atau pun wifi. 
SYSTEMIC

Vol. 03, No. 01, Agustus 2017, 33-40

2. Proses manajemen jadwal dapat dilakukan secara langsung melalui handphone.

3. Pengguna dapat mematikan suara dari kelas tertentu jika ada kegiatan yang tidak membolehkan ada suara, seperti ujian tengah semester, ujian akhir semester, dan lain-lain.

4. Amplifier harus mati jika tidak digunakan lebih dari 10 menit.

5. Sistem harus mampu mengisi ulang baterai handphone secara otomatis.

\section{B. Desain Sistem}

Kebutuhan fungsional, di gambar 1, nomor 1 sampai 3 akan ditangani oleh Sistem Operasi Android melalui Bluetooth dan/wifi sedangkan kebutuhan fungsional keempat akan ditangani oleh timer, amplifier dan 12 speaker yang tersebar di seluruh kelas di SDIT Firdaus. Gambar 2 menjelaskan arsitektur cara kerja sistem secara umum.

Langkah pertama bagi pengguna adalah menyiapkan audio yang akan disuarakan. Pengguna dapat menggunakan rekaman suara asli ataupun menggunakan suara dari aplikasi text to voice. Pada penelitian ini sumber suara diambil dari Gogle Terjemahan seperti ditunjukkan di gambar 3 dan direkam langsung menggunakan aplikasi Au.

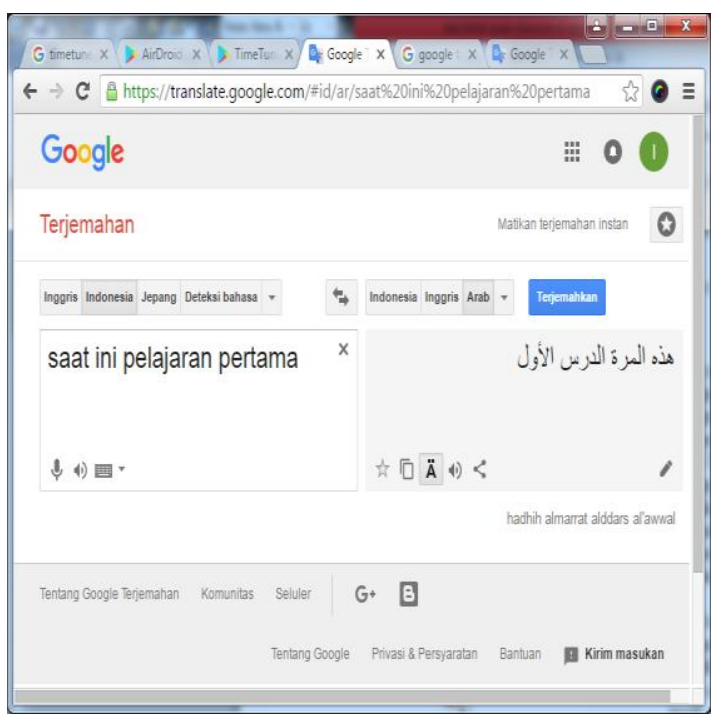

Gambar 2 Google Terjemahan untuk menyuarakan suara bahasa arab

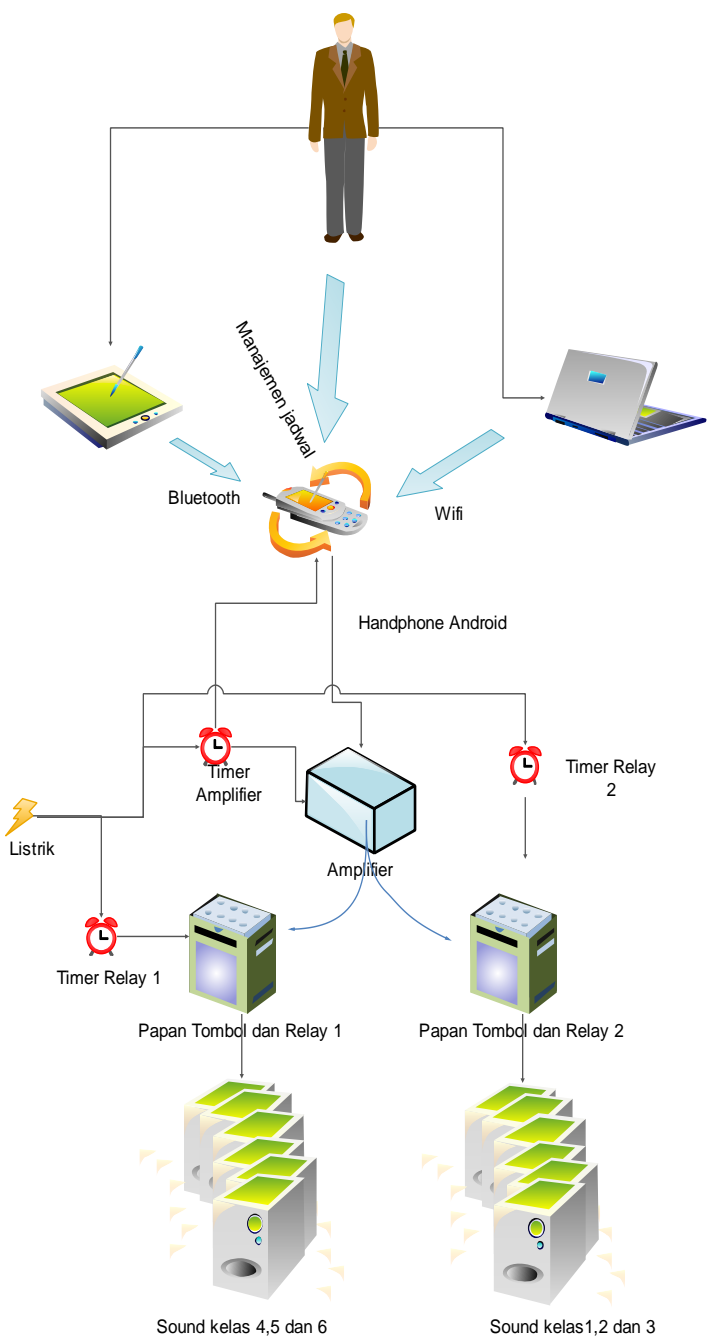

Gambar 3 Cara kerja sistem dacity.

Proses editing ditujukkan di gambar 4.

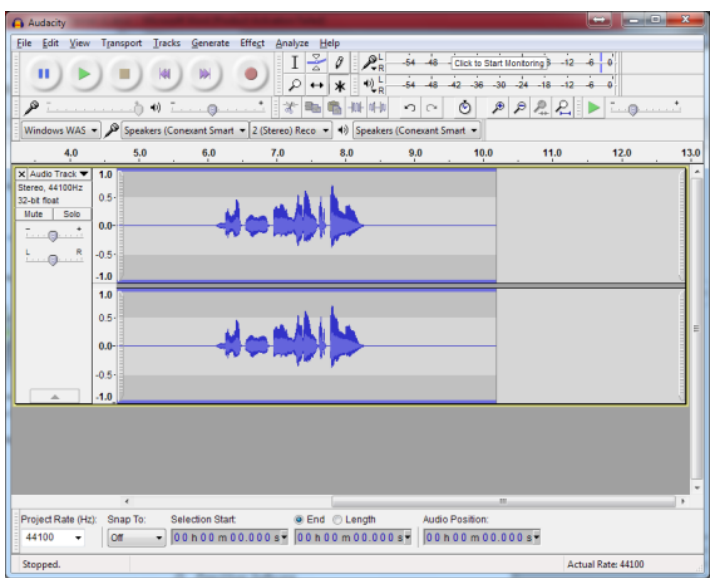

Gambar 4 Aplikasi Audacity 


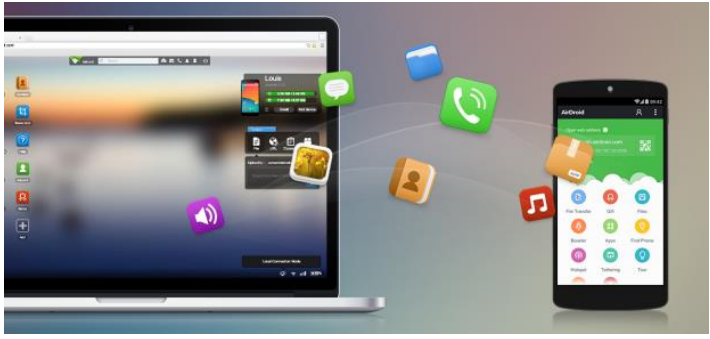

Gambar 5 Aplikasi AirDroid

Setelah file selesai diedit, selanjutnya file dikirimkan ke handphone untuk dijadwal. Untuk mengirimkan file, pada penelitian ini digunakan aplikasi Airdroid untuk mengirimkan file dari komputer ke handphone dengan menggunakan Wifi. Gambar 5 menunjukkan proses pengiriman file dari hanphone menuju komputer dengan menggunakan browser.

Setelah file tersimpan di handphone, file ini akan diputar sesuai dengan jadwal. Aplikasi yang digunakan untuk menyelesaikan tugas ini adalah TimeTune. Aplikasi TimeTune adalah aplikasi untuk meningkatkan produktifitas pribadi. Fitur dari aplikasi ini adalah sebagai berikut.

1. Manajemen waktu berdasarkan aktifitas rutin.

2. Aktifitas rutin dapat berupa harian, mingguan, atau menggunakan angka hari sampai 15.

3. Jadwal rutin bekerja seperti kalender namun tanggal tidak perlu dimasukkan

4. Mampu untuk disain dan mengirimkan jadwal untuk orang lain.

5. Mampu melakukan pemberian tag sebagai penanda aktifitas secara sekilas

6. Mampu memberitahukan pemberitahuan secara independen(getar, suara, pesan personal, popup window dan bahkan suara).

7. Statistik rutin untuk analisa dan meningkatkan distribusi durasi waktu aktifitas yang berguna untuk mendeteksi kebocoran waktu

8. Widget yang dapat diatur tampilannya
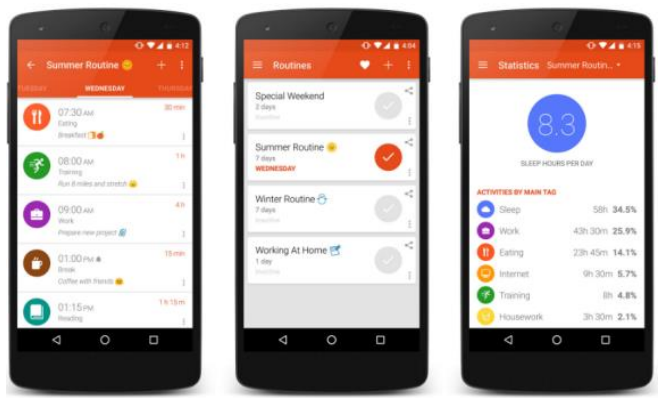

Gambar 6 Tampilan aplikasi TimeTune[4]

Ada 3 timer yang digunakan. Timer amplifier bertanggung jawab untuk mematikan amplifier jika tidak digunakan untuk menghemat listrik.
Handphone android terus menyala dan memainkan musik sesuai dengan jadwal yang sudah dimasukkan pengguna.

Suara dari handphone selanjutnya dikeraskan oleh amplifier ke suara.

\section{Disain Interface Alat}

\section{Pembuatan Alat}

Tahapan ini terdiri dari beberapa tahapan: (1) Disain interface (2)Pembuatan daftar belanja alat dan bahan (3) Pembelian alat dan bahan (4) Pembuatan alat (5) Pengujian alat.

\section{E. Pengujian Alat}

Pengujian dilakukan dengan menguji ketepatan waktu bel berbunyi dengan jadwal yang telah dirancang. Jadwal bel di SDIT Firdaus ditunjukkan di table 1. Jadwal A adalah jadwal untuk kelas 1(3 kelas) dan 2 (3 kelas). Jadwal B adalah jadwal untuk kelas 3(2 kelas),4(2 kelas),5 dan 6.

\begin{tabular}{|c|c|c|c|c|}
\hline No & Waktu & Suara & $\begin{array}{l}\text { Jadwal } \\
\text { A }\end{array}$ & $\begin{array}{l}\text { Jadwal } \\
\text { B }\end{array}$ \\
\hline 1 & 06.00 & $\begin{array}{ll}\text { Surat } & \text { Al } \\
\text { Waqiah dan } & \text { Al } \\
\text { Mulk } & \\
\end{array}$ & & \\
\hline 2 & 06.30 & $\begin{array}{l}\text { Bimbingan } \\
\text { Membaca } \\
\text { Alquran, Sholat } \\
\text { Dhuha, doa } \\
\text { awal mengaji } \\
\text { (Kalamun } \\
\text { qodiimun...) }\end{array}$ & & \\
\hline 3 & 08.00 & $\begin{array}{l}\text { Jam pelajaran } \\
\text { ke-2 }\end{array}$ & & \\
\hline 4 & 09.00 & $\begin{array}{l}\text { Jam pelajaran } \\
\text { ke-3 }\end{array}$ & & \\
\hline 5 & 09.01 & Istirahat & & \\
\hline 6 & 09.03 & $\begin{array}{ll}\text { Surat } & \text { Al } \\
\text { Waqiah dan } & \text { Al } \\
\text { Mulk } & \\
\end{array}$ & & \\
\hline 7 & 09.30 & $\begin{array}{l}\text { Jam pelajaran } \\
\text { ke-3 }\end{array}$ & & \\
\hline 8 & 09.31 & Istirahat & & \\
\hline 9 & 09.33 & $\begin{array}{ll}\text { Surat } & \text { Al } \\
\text { Waqiah dan } & \text { Al } \\
\text { Mulk } & \\
\end{array}$ & & \\
\hline 10 & 10.01 & $\begin{array}{l}\text { Jam pelajaran } \\
\text { ke-3 }\end{array}$ & & \\
\hline 11 & 10.30 & $\begin{array}{l}\text { Jam pelajaran } \\
\text { ke-4 }\end{array}$ & & \\
\hline 12 & 11.00 & $\begin{array}{l}\text { Jam pelajaran } \\
\text { ke-4 }\end{array}$ & & \\
\hline 13 & 11.01 & $\begin{array}{l}\text { Jam pelajaran } \\
\text { ke-5 }\end{array}$ & & \\
\hline
\end{tabular}




\section{SYSTEMIC}

Vol. 03, No. 01, Agustus 2017, 33-40

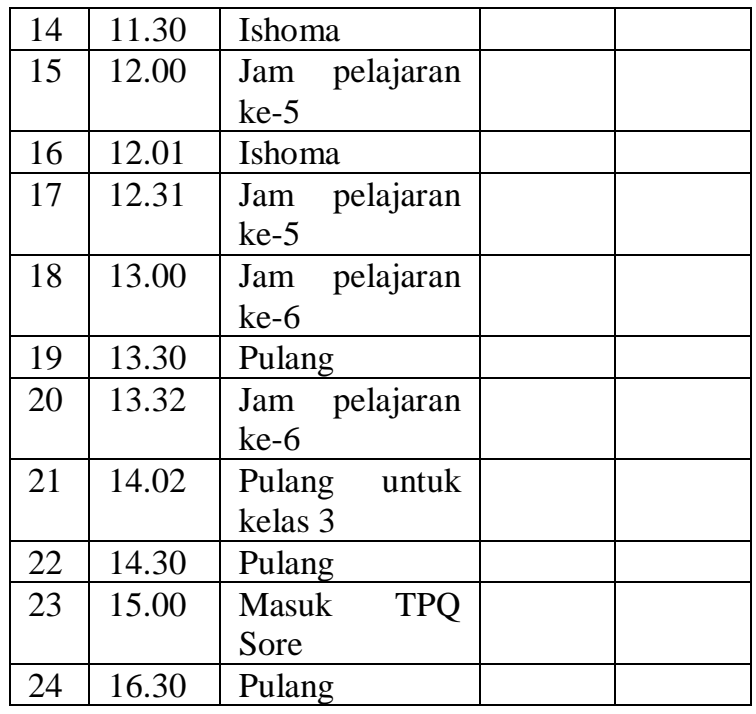

\section{HASIL DAN PEMBAHASAN}

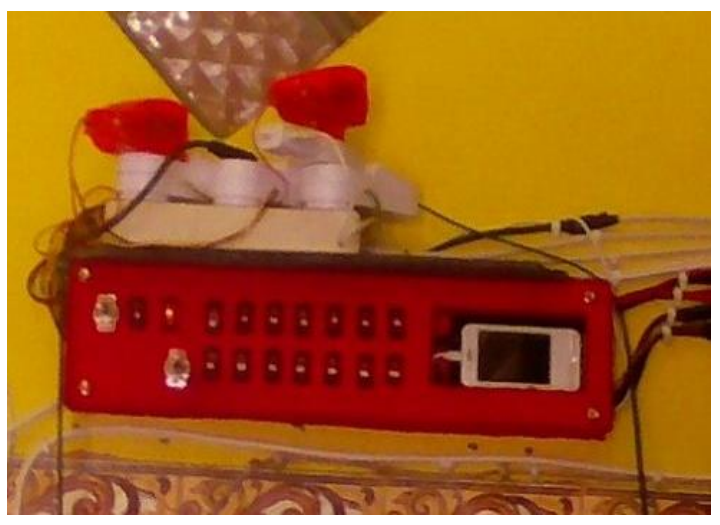

Gambar 8 Hasil akhir produk

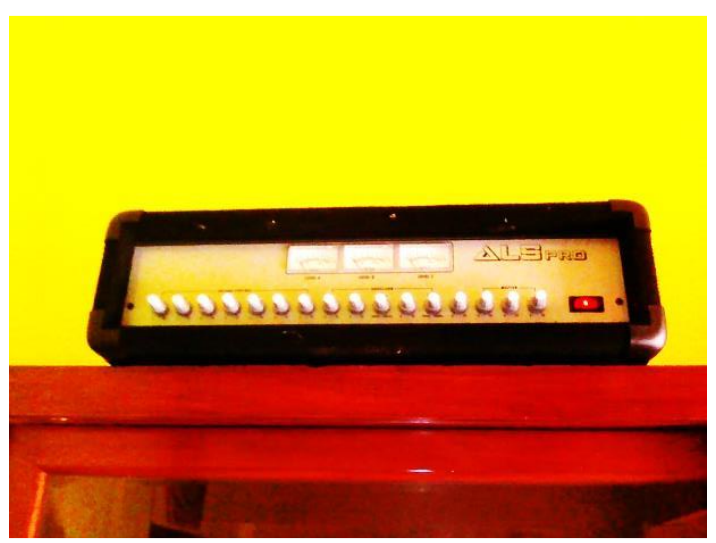

Gambar 9 Amplifier 450 Watt

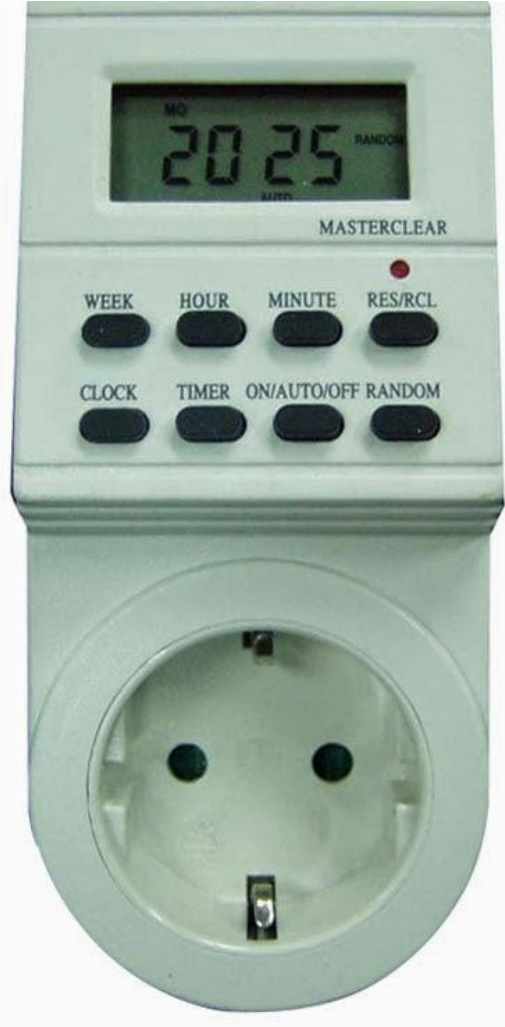

Programmable Timer Digital Kitani merupakan alat listrik sederhana dalam bentuk stop kontak yang fleksibel dapat digunakan untuk otomatisasi operasional (ON/OFF) berbagai macam peralatan listrik rumah tangga sesuai dengan waktu yang dikehendaki.

Programmable Digital Timer Kitani memiliki kemampuan otomatisasi $8 \mathrm{x}$ timer $\mathrm{ON}$ dan $8 \mathrm{x}$ timer OFF untuk kurun waktu harian hingga mingguan dan dapat di ulang setiap minggunya. Timer ini memiliki kepresisian waktu hingga satu menit dan kemampuan beban power maksimal hingga 3600 Watt. 


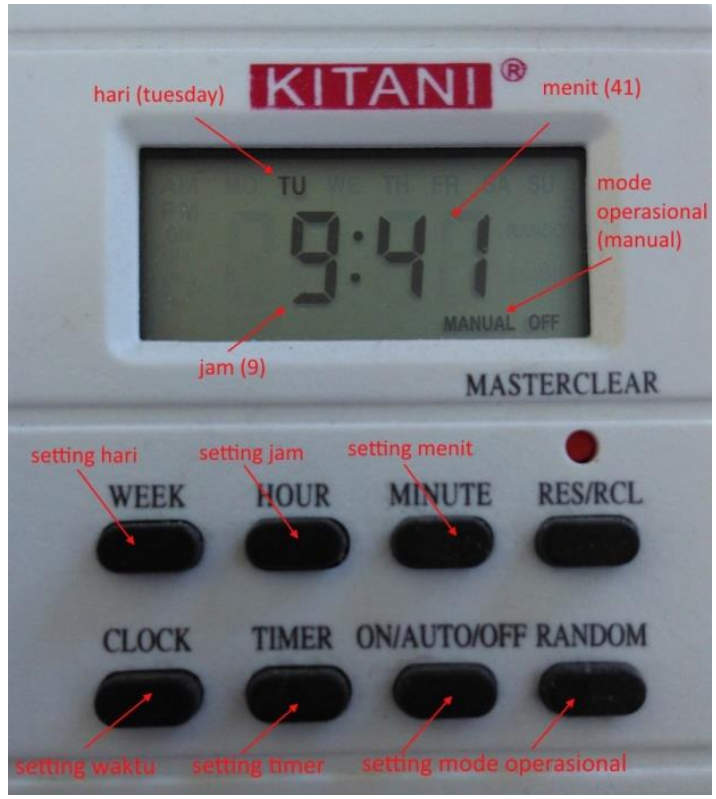

Gambar 10 Timer Kitani, 8 waktu nyala dan 8 waktu off

A. Tahapan Setting Programmable Timer Digital Kitani :

Terdapat dua tahapan / kategory pengaturan (setting) yaitu pengaturan Waktu (Clock) dan pengaturan otomatisasi ON dan OFF (Timer), dimana masing-masing memerlukan setting hari, jam dan menit.

\section{B. Pengaturan Waktu (Clock)}

Setting Hari, untuk setting hari silahkan tekan tombol "CLOCK" jangan dilepas dan di ikuti dengan menekan tombol "WEEK" beberapa kali hingga display hari (MO, TU, WE, TH, FR, SA atau SU) telah sesuai.

Setting Waktu, untuk setting waktu silahkan tekan tombol "CLOCK" jangan dilepas dan di ikuti dengan menekan beberapa kali tombol "HOUR" untuk mengatur Jam atau tekan beberapa kali tombol "MINUTE" untuk mengatur menit hingga sesuai.

\section{Pengaturan Otomatisasi Timer}

Setting Hari, untuk setting hari silahkan tekan tombol "TIMER" kemudian tekan tombol "WEEK" beberapa kali hingga display hari (MO, TU, WE, TH, FR, SA atau SU) telah sesuai dengan yang dikehendaki. Pilihan hari bisa lebih dari satu (berulang).

Setting Waktu Timer, untuk setting waktu timer silahkan tekan tombol "TIMER" beberapa kali dan amati perubahan pada display, ON artinya setting timer untuk ON dan OFF artinya setting timer untuk OFF, angka 1 dst adalah nomor urutan timernya

Setting Jam dan Menit Timer, untuk setting Jam tekan beberapa kali tombol "HOUR" untuk mengatur Jam dan tekan beberapa kali tombol "MINUTE" untuk mengatur menit hingga sesuai.

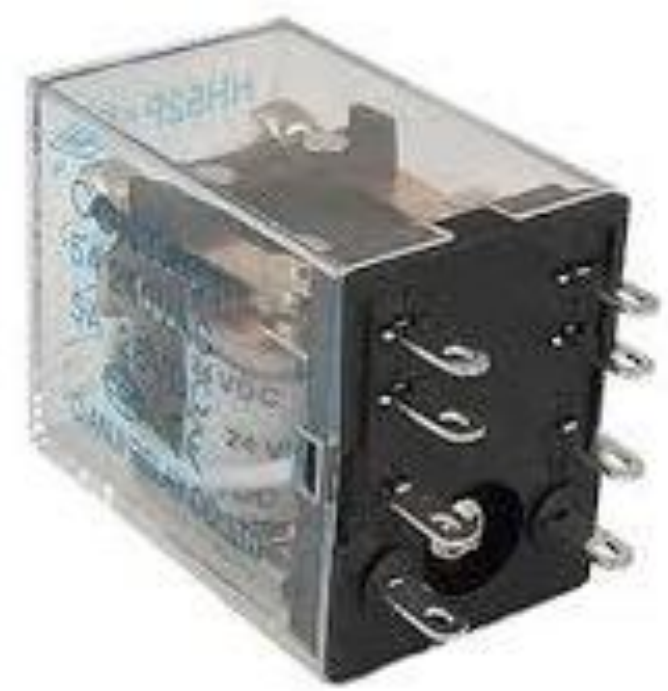

Gambar 11 Relay 8 kaki

Pada relay LY2 terdapat 2 buah kontak input utama yang disimbolkan oleh angka 5 dan 6 . Masing-masing kontak terdiri dari 2 buah output yang berada dalam kondisi NO (3 dan 4) dan NC (1 dan 2). Sedangkan angka 7 dan 8 merupakan power koil relay yang nantinya berfungsi untuk memindahkan kontak relay dari NC ke NO atau sebaliknya. Lihat gambar berikut :

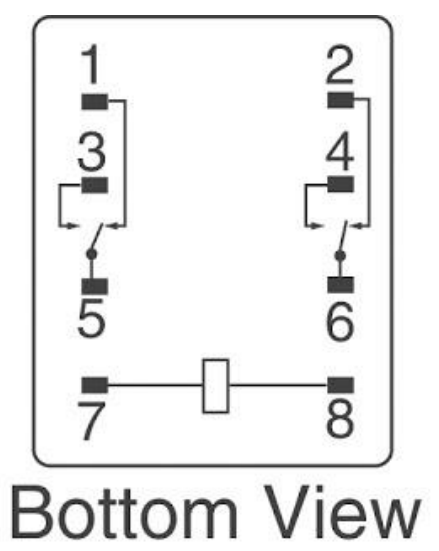

Gambar 12 Struktur Relay 8 kaki

Prinsip kerjanya adalah ketika anda memberikan power pada terminal nomor 7 dan 8 , maka akan timbul medan magnet pada pada koil relay 


\section{SYSTEMIC}

Vol. 03, No. 01, Agustus 2017, 33-40

sehingga kontak relay yang tadinya berada pada posisi NC (1 dan 2), akan berpindah ke posisi NO (3 dan 4) karena tarikan medan magnet yang ditimbulkan oleh koil (lilitan) dalam relay tersebut. Ketika anda memutus arus menuju angka 7 dan 8, maka kontak relay akan kembali ke posisi semula. Begitu seterusnya.

Relay jenis ini biasanya banyak digunakan pada perusahaan-perusaan industri sebagai komponen system keamanan jaringan listrik. Di penelitian ini relay ini digunakan untuk menyalakan alarm sesuai dengan waktu yang dikontrol oleh timer kitani.

\section{KESIMPULAN}

A. Kesimpulan

Pada penelitian ini dibuat sistem pengumuman dual channel menggunakan aplikasi android. Sistem sudah berfungsi sesuai dengan harapan pengguna.

B. Saran

Saran untuk penelitian mendatang adalah sebagai berikut.

1. Adanya batasan timer yang hanya $8 \mathrm{kali}$ on dan 8 kali off membatasi jumlah waktu yang ada, penelitian mendatang dapat menggunakan raspberry atau arduino untuk mengatasi masalah terbatasnya jumlah memori timer ini.

2. Dapat diusulkan untuk sekolah besar yang memiliki lebih dari 2 channel.

\section{DAFTAR PUSTAKA}

[1] Mochamad Subianto. (2015). Sistem Bel Otomatis Terprogram Berbasis Raspberry Pi. SMATIKA Jurnal. volume 05 (Nomor 01). Tersedia: jurnal.stiki.ac.id/index.php/smatika/article/download/70/ 76

[2] Sand Studio(2016). Airdroid Tersedia: https://play.google.com/store/apps/details?id=com.sand. airdroid\&hl=in

[3] Sahabat TEkno.(2016). Panduan Setting Programmable Timer Digital Kitani. Tersedia: http://sahabattekno.com/panduan-setting-programmabletimer-digital-kitani/

[4] Time Tune Studio. (2016). TimeTune. Tersedia: https://play.google.com/store/apps/details?id=com.gmail. jmartindev.timetune \&hl=in

[5] As Siraaj. (2016). Relay dan Cara Kerjanya. Tersedia: http://www.lentera-kita.com/2015/07/relay-dan-prinsipkerjanya.html 
